\title{
The Sister Village Program: Evaluation of Refugee Camp in Deyangan Village, Magelang District in Merapi Preparedness
}

\author{
Margono ${ }^{1}$, Priyo ${ }^{2}$, Akhmad Liana Amrul Haq ${ }^{3}$ \\ \{margono@ummgl.ac.id ${ }^{1}$ \} \\ Faculty of Health Science, University of Muhammadiyah Magelang, Indonesia ${ }^{1,2}$ \\ Faculty of Psychology, University of Muhammadiyah Magelang, Indonesia ${ }^{3}$
}

\begin{abstract}
The research objective was to evaluate the readiness of the Peyangga village and increase preparedness in evacuating refugees. The research design was a mixed method with a survey approach and FGD (Focus Group Discussion). The survey results on the suitability of the contingency plan and the readiness of the buffer sites indicate that it is appropriate. Evacuation locations have been provided taking into account the number of survivors of Krinjing village. At level 3 (standby), evacuation has been carried out for vulnerable groups: the elderly, toddlers, pregnant women, breastfeeding mothers, and groups with disabilities. Management of Logistical needs at the beginning was not optimal, however, after one week of implementation, management was carried out properly and transparently, especially recording logistic income and expenditure. In the field of education, an activity program has been structured and can run well, however in the field of economic and animal husbandry programs, preparations have not been made as planned. The results of the FGDs support that the contingency plan is good, but it is necessary to prepare the buffer villages in the livestock and economic sectors. To follow up the anticipation of the level increase, additional barracks for evacuation will be carried out and preparation of evacuation land for livestock.
\end{abstract}

Keywords: Sister vallage, Evaluasi, Contingensi Plan

\section{Introduction}

Mount Merapi is one of the active volcanoes in the world, located in the Central Java region and the Special Region of Yogyakarta. Mount Merapi has specific characteristics for its type of eruption, which produces hot clouds or wedus gembel in Javanese terms or nuée ardente in scientific terms. A primary hazard caused by the eruption of Merapi which consists of gas, rock and volcanic ash which are usually preceded by lava flows and collapsed lava domes. However, historical records have shown that often the eruptions of Mount Merapi occurred with different mechanisms, for example in 1872 and 2010 which occurred explosively [1], [10]. The impact caused by the eruption is the destruction of ecosystems as well as the loss of the potential of forests as providers of oxygen, carbon sinks and habitat for various unique flora and fauna that exist on Mount Merapi [8].

The time of the eruption of Mount Merapi cannot be ascertained. Like now, it has been 2 years at the alert level. The eruption of Mount Merapi in 2010 shows that the disasters caused by the eruption have caused enormous damage. This incident caused 1,705 injured victims, 
consisting of 1,412 minor injuries and 293 serious injuries, 332 fatalities and 4,874 victims who experienced psychological disorders [1]. In addition to the problem of casualties, there will also be problems with unclear refugee camps and the village government having difficulty finding information on the fate of people in evacuation who do not know their whereabouts. To anticipate the impact of the eruption of Merapi in the disaster mitigation process, Magelang District has implemented a sister village program with the concept of one village in a disasterprone area having a buffer village in a safe area. However, in an effort to apply the sister village concept, it is necessary to conduct an evaluation so that it does not cause new disasters in the buffer village location. With the increase in the alert status set by BPPPTKG on November 5, 2020, efforts that have been made in Deyangan Village as a refugee buffer village for Krinjing Village are the preparation of refugee barracks.

Deyangan Village has been making preparations for the past two years by preparing contingency plans that have been carried out in previous simulations. Previous research conducted by Wilybrodus [9] conducted in Ngargomulyo village in a disaster-prone village area showed that the concept of sister vallage is more organized, logistical readiness is more accurate, but the readiness of refugee camps has not matched the needs in terms of capacity and is still prone to conflicts between buffer villages with refugee villages. So, the need for common perceptions with the preparation of contingency plans together.

In this study, an evaluation of the suitability of the buffer village readiness will be carried out with the plans that have been prepared, both regarding the management of evacuation places, facilities, logistics, education and the economy. After this research is carried out, it is hoped that it can improve the preparedness of the buffer villages, especially in the readiness of the refugee barracks which is one of the most important factors in the disaster management of the eruption of Merapi.

\section{Method}

The research design was a mixed method with a survey approach and FGD (Focus Group Discussion). At the survey stage, evaluating the contingency planning documents with the preparedness of the refugee camps that have been prepared. After that, it was followed by an FGD involving the posko management, refugees and the village government. The FGD was attended by 17 people, taking care of the village administration, the asistance team of the post / final ecacuation site, the krinjing village volunteer team and the deyangan village volunteer team. In this FGD stage, the evaluation and suitability of between planing with the fact done about the places of confinement will be discussed, such as the number of evacuation booths, the facilities provided, logistics management, health services, education, religion, psychosocial and economic conditions. Each the participant will submid an evaluation of each area management. This research was conducted in Deyangan Village in October-November 2020.

\section{Results and Discussion}

\subsection{Contingency plan conformity}

The survey results on the suitability of the contingency plan with the readiness of the buffer sites show that the provision of refugee camps is carried out when Mount Merapi is at the alert 
level. Has been built in the buffer village housed in the village hall Deyangan. The facilities that have been established are public kitchens, toilets and bathrooms, logistic warehouses, health service places, coordination posts, and places of worship that are adequate and have prepared a health protocol for the prevention of covid-19. From the survey above, physically its provision has been carried out in accordance with the contingency plan. However, the number of final evacuation sites (TEA) shows that it does not match the capacity of the population of Krinjing Village. Currently there are 50 rooms that can be used in one family for each room. For evacuation at this alert level, namely for vulnerable groups so that the buffer village can meet the current number of refugees as many as 127 people out of 38 households. The survey results show that the current unpreparedness is in providing shelter and livestock management.

The results of the FGD implementation indicated that there was still insufficient provision of shelter, especially for later when the status of Merapi increased. This supports the results of the survey that the contingency plan is good, but it is necessary to make preparations for the villages in the number of evacuation places. In the logistical sector, health, religious, education and psychosocial facilities have been well planned, but it is necessary to consider additional land if the number of refugees increases. The things where there is no maximum readiness are in the livestock and economic sectors. The results of the FGD agreed that it was necessary to provide a large area for livestock because there were 954 cows and 134 goats that had to be given space.

\subsection{Discussion}

This study evaluates the suitability of the contingency plan with the readiness of the buffer village with the plans that have been compiled in the sister village program. It shows that the implementation of village preparedness has been substantially good. However, in terms of numbers, they are still in the process of providing refugee camps, facilities, logistics management, education services, health services and the economy / livestock.

Research supports the research conducted by Willybrodus [9] which was conducted in the Ngargomulyo sub-district, Magelang Regency, which shows that with the sister village concept, refugees will be more organized, monitored by the village government and feel safe and comfortable. However, it was not easy to form this sister village. Research conducted by Fiqih [5] in Boyolali district shows that the community is not familiar with the sister village program even though they have been displaced and there are several villages that refuse because the facilities are not yet available, especially in terms of livestock. Deyangan Village as a buffer village in this sister village program has been carried out by research by Kanti [7] which states that the buffer village community and refugees in terms of knowledge have increased, especially the existence of an early warning system and the LPBDes of Deyangan Village has been formed to mitigate the Merapi eruption disaster as a village Buffer.

The research we conducted looked at the readiness of the buffer villages in applying the contingency plans that had been prepared by the two sister villages previously. In the event that the village evacuation post has been provided with a centralized communication facility with the Regional Disaster Management Agency of Magelang Regency, the monior of Merapi's volcanic activity which is directly connected to the Merapi monitoring post in Babadan, Magelang district, IDP data information system, logistic monitoring system, clear post organizational structure. and security which continues to be carried out according to the picket schedule. 


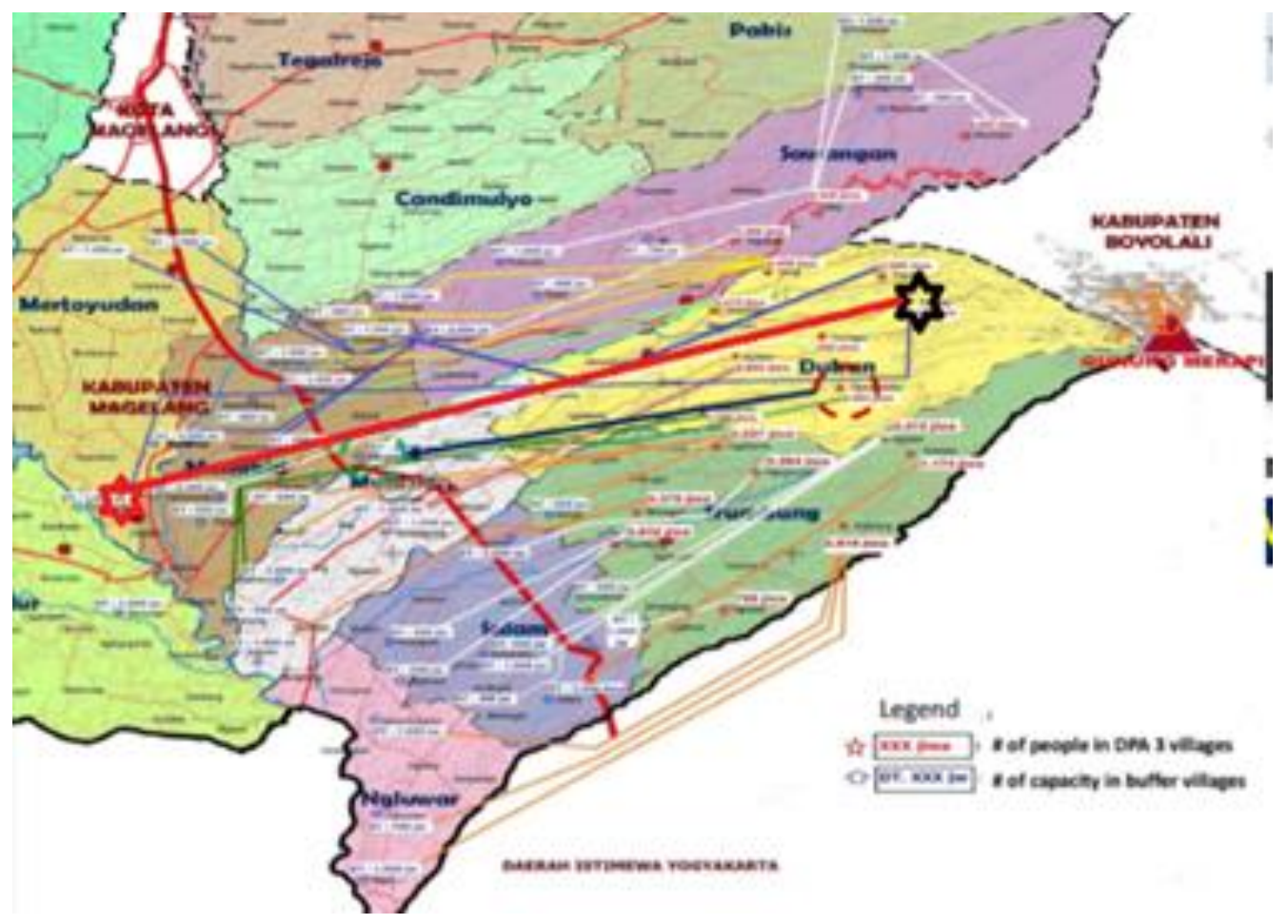

Fig. 1. Merapi eruption areas

In the population evacuation sector, this research has carried out a good planning through an evacuation contingency plan. Safety in carrying out health services, especially nursing. According to the technical guidelines for crisis / emergency response, it shows that health /nursing services in disaster management are very important, both from evacuation, field services and evacuation services. These services include emergency and psychosocial services. In carrying out the evacuation, health workers were carried out and at TEA Deyangan, a rapid test was carried out for the prevention of covid transmission.

In the refugee barracks sector the United Nations High Commission of Refugees (UNHCR) in 2000 stated that the need for temporary evacuation space is $3.5 \mathrm{~m}^{2}$ per person. At present, the Deyangan Final Evacuation Site (TEA) has built 50 booths with a size of $2.4 \mathrm{~m}^{2}$ per room. With a building area of $664 \mathrm{~m}$, currently it is inhabited by 127 people, indicating that there is still a lack of area for the refugees. According to research conducted by Farida, a settlement should ideally contain two main requirements, namely, the physical environment must reflect the pattern of life and cultural patterns of the displaced population, and the residential environment must be supported by adequate service facilities that are proportional to the size or extent of the environment and the number of refugees. Therefore, it is necessary to carry out good contingency planning in collecting data on refugees with the capacity of refugee camps.

According to Fauzi [4], facilities that have the number of basic needs of refugees that must be met include the needs for clean water, nutrition, toilets, sanitation and garbage, as well as the need for love rooms. The availability of toilets in TEA with 18 bathrooms, this shows that it is still ideal for refugees to use because the standard needs of 1 MCK can be used by 20-30 people. 
Meanwhile, health facilities have been prepared in the health protocol by constructing a hand washing place and providing a hand sanitizer, for the need for clean water it has been carried out according to the contingency by being supplied by BPBD and PDAM. For sanitation and also love booths in this refugee camp have also been provided properly.

The majority of Krinjing villagers are farmers and breeders. In the contingency plan, there are data on 954 cows and 134 goats that will be evacuated if there is an increase in alert level status. In this sister village, it applies the concept that village siblings can provide the needs of their village. This research shows that there is no readiness in the buffer villages in an effort to prepare a place for the livestock sector. The results of the FGD agreed that there was land clearing provided by the Peyangga Village as a location for livestock locations. Willibrodus' research [9] states that livestock is often a problem in sister village programs. The availability of land is something that needs to be done in solving the solution to the problem of livestock. Apart from that, differences in types of forage and management of livestock prices must also be important to find solutions. The need for further research and discussion in the field of animal husbandry and the economy of refugee communities.

Two other concepts that are no less important in the sister village program are learning assistance and psychosocial support. The purpose of holding the concept of learning assistance and psychosocial support is twofold, first to maintain the learning atmosphere so that it is maintained, someone who leaves the learning atmosphere for too long will feel lazy to start again, secondly to provide new knowledge and skills to survivors with the hope that when the situation is tidy back to normal there is new knowledge that can be used in his hometown, in planning the concept of learning assistance can be seen in the Table 1.

Table 1. Planing the concept Management

\begin{tabular}{|c|c|c|c|}
\hline Aspect & $\begin{array}{l}\text { Examples of } \\
\text { activities }\end{array}$ & Purposes & Target \\
\hline Education & Sekolah pagi & $\begin{array}{l}\text { So that the face-to-face school } \\
\text { atmosphere can still be run so } \\
\text { that the spirit of the school is } \\
\text { maintained }\end{array}$ & $\begin{array}{l}\text { School Age } \\
\text { Children }\end{array}$ \\
\hline Religious & $\begin{array}{l}\text { Al-Qur'an Education } \\
\text { Park (TPA) } \\
\text { religious studies }\end{array}$ & $\begin{array}{l}\text { So that the spiritual atmosphere } \\
\text { is maintained } \\
\text { So that the spiritual atmosphere } \\
\text { is still maintained }\end{array}$ & $\begin{array}{l}\text { School Age } \\
\text { Children } \\
\text { All Age }\end{array}$ \\
\hline Health & $\begin{array}{l}\text { Medical Chek } \\
\text { gymnastics for the } \\
\text { elderly }\end{array}$ & $\begin{array}{l}\text { Maintain physical health } \\
\text { Maintain physical health }\end{array}$ & $\begin{array}{l}\text { All Age } \\
\text { elderly people }\end{array}$ \\
\hline $\begin{array}{l}\text { Provision of } \\
\text { skills }\end{array}$ & $\begin{array}{l}\text { Waste material } \\
\text { processing }\end{array}$ & Adding new knowledge & All age \\
\hline Refresing & Mini outbond & Eliminate boredom & All age \\
\hline
\end{tabular}

The concepts in the Table 1 will work well if there is a person in charge of the activity and scheduled time in every aspect. Psychosocial support is the last concept of concern. Many interpret psychosocial support and trauma healing as one and the same meaning, even though these two things are two different things. According to Quin, trauma healing is a healing intervention given to someone who is traumatized by an incident, the mention of the word trauma itself must go through a series of rigorous psychological examinations, while psychosocial support is giving motivation and support to someone who is in crisis. or a disaster 
situation, so that in dealing with it a person does not feel alone [6]. The existence of this concept is expected that when the sister village program is running, the activities carried out will be measurable and useful, this concept can also be a guide if there are communities / volunteers who want to participate in parcipating there are corridors / rules that must be followed, including a health certificate free of covid 19 and the number of volunteers who will fill the activity.

\section{Conclusion}

Based on this research, it shows that this sister village program is able to be a solution in the management of Merapi eruption refugees, with good contingency planning, the refugees will be more organized, monitoring the village government is easy and minimizing casualties and able to prevent disaster risk management, especially Merapi. What needs to be improved is the contingency plan for the management of the livestock sector and the economy to make people displaced and prevent the risk of danger because sometimes people prefer to save the lives of their livestock rather than their lives.

\section{Acknowledgement}

The author says many thank to the village government of Deyangan and Krinjing village who have provided the opportunity for researchers to collect data and provide assistance to refugee posts in implementing sister village-based contingency plans. Not to forget, we would like to thank the Magelang District BPBD for facilitating and entrusting the assistance of the village support post.

\section{References}

[1] Brotopuspito, Kirbani Sri, Suratman, Pramumijoyo, Subagyo, Hadmoko, Danang Sri, Harijoko, Agung; dan Suyanto, Wiwit.( 2011). Kajian Multi Bahaya, Kerentanan, Risiko, Desain Tata Ruang Kawasan Rawan Bencana Merapi dan Implementasinya dalam Peningkatan Kapasitas dan Kesiapsiagaan Masyarakat Terhadap Bahaya Gunungapi. Laporan Penelitian. Hibah Penelitian Strategis Nasional Universitas Gadjah Mada.

[2] Dillashandy, N. A.,\& Pandjaitan,N.K.(2018). Kapasitas Adaptasi Dan Resiliensi Komunitas Menghadapi Bencana Erupsi Gunung Merapi. Junal Sains Komunikasi dan Pengembangan Masyarakat (JSKPM), 2(5): 617-26

[3] Dwi Rustiono Widodo (2017) Analisis Penyebab Masyarakat Tetap Tinggal di Kawasan Rawan Bencana Gunung Merapi (Studi di Lereng Gunung Merapi Kecamatan Cangkringan, Kabupaten Sleman Daerah Istimewa Yogyakarta), Jurnal Ilmu Lingkungan Volume 15 Issue 2: 135-142

[4] Fauzi (2012), Grand Desain Simulasi Bencana Merapi 2014 Solusi Perencanaan dan Pengelolaan Aspek Kesehatan Masyarakat Pengungsi, Jurnal Ilmiah Mahasiswa, Vol. 2 No.2, September 2012

[5] Fiqih (2019). Mitigasi bencana gunung merapi berbasis desa bersaudara (sister village) di kecamatan musuk kabupaten boyolali jawa tengah

[6] Hendrik (2019). The burden of mental disorders and access to mental health and psychosocial support services in Syria and among Syrian refugees in neighboring countries: a systematic review

[7] Kanti, Pamungkas (2018). Sistem informasi desa dalam mitigasi bencana (peran desa penyangga 
dalam implementasisister village

[8] Marhaento, H. \& Kurnia, A. N. (2015). Refleksi 5 Tahun Paska Erupsi Gunung Merapi 2010: Menaksir Kerugian Ekologis di Kawasan Taman Nasional Gunung Metrap. Geoplanning: Journal of Geo matics and Planning,

[9] Willybrodus (2017) analisis implementasi sister village sebagai upaya penanggulangan bencana erupsi gunung merapi dalam status aktif normal (pra bencana) di kabupaten magelang

[10] Voight, B., Constantine, E.K., Siswowidjoyo, S., dan Torleya, R. 2000. Historical Eruptions of Merapi Volcano, Central Java, Indonesia, 1768-1998. Journal of Volcanology and Geothermal Research. Vol. 100, 69-138. 